\title{
菱形三角フィンによる衝撃波と境界層の干渉*1 Shock Wave/Boundary Layer Interactions Induced by a Rhombic Delta Fin
}

\author{
斎田暢 三*2 $\cdot$ 緒 方 良 太 $*^{* 3} \cdot$ 小出俊 輔*4 \\ Nobumi SAIDA, Ryota Ogata and Shunsuke KoIDE
}

Key Words : Viscid-Inviscid Flow Interaction, Boundary Layer, Shock Waves

\begin{abstract}
This paper presents an experimental and numerical study of shock wave/turbulent boundary layer interaction induced by rhombic delta fins placed on the side wall of the test section. The experiments were carried out in $80 \times 100 \mathrm{~mm}^{2}$ supersonic wind tunnel at free stream Mach number of 2.50. Corresponding free stream unit Reynolds number was $3.74 \times$ $10^{\circ} / \mathrm{m}$. Five models were used in this study. The fin half apex angles were $12^{\circ}, 18^{\circ}, 24^{\circ}$ at $30^{\circ}$ sweepback angle and for the fin sweepback angles $15^{\circ}, 45^{\circ}$ at $18^{\circ}$ half apex angle. Schlieren photographs, oil flow measurements and wall surface static pressure measurements were made. It was found that the upstream influence line runs parallel to the primary separation line and obeys the Reynolds number scaling law. Furthermore, the primary separation angle $\beta_{\mathbf{s l}}$ can be accounted for by referencing $\beta_{\mathrm{s} 1}$ and $\beta_{0}$ to Mach angle $\mu_{\infty}$.
\end{abstract}

\section{1. まえがき}

超音速または極超音速で飛行する飛翔体の表面，例えば 翼と胴体，または制御面近くでは衝撃波と境界層の干涉が 生し，空気力学的な性能に有害な影響をもたらす．そのた め,いままでに多くの研究が行われてきた，特に三次元物 体については円柱，または半円柱とフィンの結合体，ある いは主流に対して迎え角をもった平板などによる衝撃波と 物体が扔かれている平板上に発達した境界層との干涉を取 り扱ったものが多い1,2).しかし三次元物体の幾何学的形 状が多様であるため，いまだに完全に解明されていない． 近年, 種々の形状一後退角のある場合とない場合の鋭いフ イン，半円錐または菱形三角フィンなど一を統一して表す 方法が研究されている3 8). また Alvi ら9によるフィンに ついての研究結果よりフィンによって発生する衝撃波の波 面に垂直な領域の状態は，フィンの迎え角に関係なく衝撃 波波面に垂直なマッ八数に依存することが明らかにされ た。したがって、物体によって発生する衝撃波の形状が求 まれば，流れ場の解明に役立つものと考えられる．このよ うな理由で衝撃波の形状やはく離点を求める簡易計算法が 報告されている ${ }^{10,11)}$. 勿論, 物体と衝撃波間の流れは物体 の形状に依存していることは言うまでもない．

ここではより実用的な菱形三角フィンが平板に与える影 響を見るため,フィンの半頂角と後退角を変化させて平板 上の流れの可視化と圧力分布を詳細に測定し，形状による

\footnotetext{
${ }^{* 1}$ 平成 8 年 3 月 14 日，平成 7 年度䈟艘波シンポジウムにて発表. 平成 11 年 9 月 14 日原稿受理

*2 青山学院大学理工学部

*3 青山学院大学大学院理工学研究科. 現 三菱重工業

*4 防衛庁技術研究本部第 3 研究所
}

影響を調べた。さらに非粘性流として Macormack 法に より衝撃波角や最大圧力を計算し，簡易計算法の妥当性と 鋭いフィンとの相違点等を明らかにした。

\section{2. 実験装置と方法}

本実験に使用した風洞は测定部の断面積が $10 \times 8 \mathrm{~cm}^{2}$ の 吹き出し式超音速風洞である. 実験は主流マッハ数 $M_{\infty}=$ 2.50 について行い, 対応するレイノルズ数は測定部で 1 $\mathrm{m}$ 当たり $R e=3.74 \times 10^{7}$ である.モデルが固定されてい る風洞側壁に発達する境界層は完全に乱流であり，境界層 外縁の速度の $99.5 \%$ の位置を境界層の厚さと定義した場 合 $\delta=5.0 \mathrm{~mm}$ である。また対応する排除厚と運動量厚は それぞれ $\delta^{*}=1.05 \mathrm{~mm}$ と $\theta=0.27 \mathrm{~mm}$ である。

実験に使用した菱形三角フィンモデルの幾何学的形状と 使用した座標系を第 1 図(a)，(b)に，またモデルの主要 諸元を第 1 表に示す. 同表中の $\phi$ は半頂角 $\alpha$ と後退角 $\lambda$ に関係したパラメータで次式によって定義される。

$$
\phi=\tan ^{-1} \frac{1}{\sin \alpha \tan \lambda}
$$

本実験に使用したモデルの形状は後退角 $\lambda=30^{\circ}$ に対して 半頂角 $\alpha=12,18,24^{\circ}$ と $\alpha=18^{\circ}$ に対して $\lambda=15,45^{\circ}$ の 5 種類である. Alvi と Settles ${ }^{9}$ による衝撃波前後の圧力 比と主流マッ八数に対して斜为衝撃波の垂直方向の成分を 使った干涉状態の分類によれば，本実験は干渉による一次 はく離と二次はく離が生じる範囲に対応している。

測定はモデルが固定されている平板上の圧力測定と油膜 法による流れの観察を行った。 またモデルの上からのシュ リーレン撮影により衝撃波角の測定も行った。平板表面上 には内径 $0.6 \mathrm{~mm}$ の静圧孔が $6 \mathrm{~mm}$ 間隔で $x$ 軸方向に 11 列， $y$ 軸方向に 16 列あけてあり，モデルを綎横方向に 2 


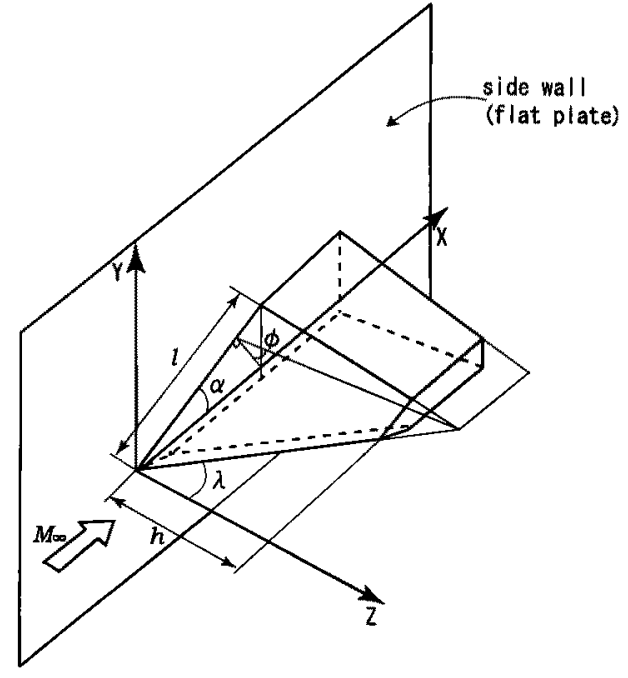

(a)

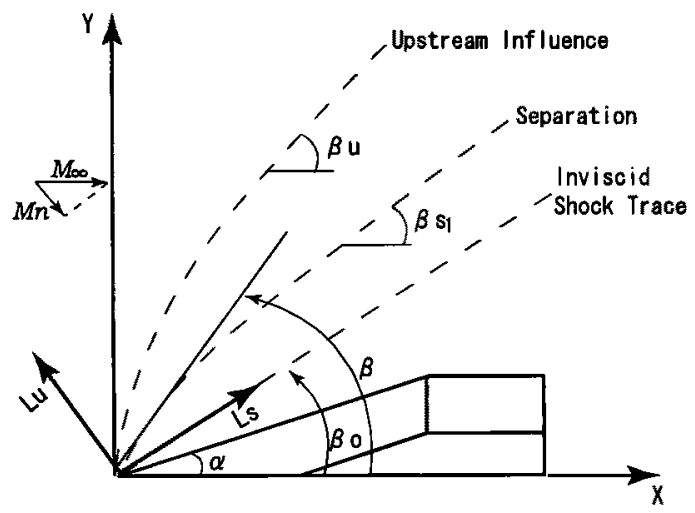

(b)

第1図（a）モデル形状と座標，(b) 座標と記号

第 1 表 モデルの主要諸元

\begin{tabular}{ccccc}
\hline$\alpha$ (deg) & $\lambda(\mathrm{deg})$ & $\phi(\mathrm{deg})$ & $l(\mathrm{~mm})$ & $h(\mathrm{~mm})$ \\
\hline 12 & 30 & 83.16 & 65 & 45 \\
18 & 15 & 85.27 & 60 & 45 \\
18 & 30 & 79.88 & 60 & 45 \\
18 & 45 & 72.83 & 60 & 45 \\
24 & 30 & 76.78 & 55 & 45 \\
\hline
\end{tabular}

$\mathrm{mm}$ 間隔で移動させることにより $64 \times 91 \mathrm{~mm}^{2}$ の領域の静 圧を $2 \mathrm{~mm}$ 間隔で測定することができる，以上の表面圧 力の測定はすべてスキャニバルブをもちいて行った．流れ の可視化ではクセノンランプを光源としたシュリーレン法 により衝撃波形状の観察を，また油膜法ではシリコン油に 二酸化チタンを混入したものに緩和剂としてオレイン酸を 調合したものを使って平板上の流れを観察した。

\section{3. 数值計算法}

超音速流中での菱形三角翼による衝撃波形状を求めるた めに三次元非粘性の Euler 方程式を次式により， $x, y, z$ 空間加 $\zeta ， \eta ， \xi$ 空間に座標変換し，錘状流として MacCormack 法により計算を行った ${ }^{12}$.

$$
\xi=x, \quad \eta=y /(x-z \tan \lambda), \quad \xi=z / x
$$

ここで $x$ は一様流の方向であり, 計算は $\zeta=\zeta_{0} て ゙ の$ 初期
值よりそ方向に始め，解が収束するまで進めた．初期条 件としてはモデルの表面を除いたすへてての点で一様流の值 を使用した，境界条件としては，1）フィンと平板表面で はそれぞれの垂直方向の速度成分を 0 とし，それ以外の值 は内点からの外挿により求めた．2）フィンに対しての側 面境界は一様流の值と，3）上方境界面での值は一つ手前 の格子点での值と等しいものとした．本計算で使用した格 子点数は $\eta, \xi$ 方向に $101 \times 51$ であり,クーラン数は 0.9 とした。

\section{4. 結果と考察}

4.1 衝撃波角 第2図(a)〜 (c) はフィンモデルを上 から撮影したシュリーレン写真である。どの写真を見ても 衝撃波はモデルの頂点より多少下流から生じているように 見える。これはモデル先端が壁面近傍の亜音速領域にある ためで後退角が大きくなるほど顕著になっている，第 2 図 (a)のモデルを見ると衝撃波は帯状になって伸びており， 後退角が小さいためフィン前緣の全体から発生しているの が判別できることを物語っている。これらの写真から読み 取った衝撃波角 $\beta_{0}$ と半頂角 $\alpha$ または後退角 $\lambda$ との関係を 第 3 図(a)，(b)に，またパラメータ $\phi$ との関係を第 3 図(c)に示す。これらを見ると $\alpha$ が大きくなるにつれ，

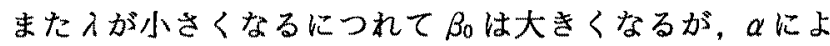
る影響に比へでによる影響の方が小さいことがわかる． なお同図中には小出ら ${ }^{10} に よ り$ Griesel の行った非粘性流 の数值計算の結果をもとにして導いた $\beta_{0} と \phi$ 関係式も 記入してある。これは衝撃波角 $\beta_{0}$ を $\phi$ 多項式で近似し たもので次式によって表される。

$$
\begin{aligned}
& \frac{\beta_{0}}{\beta_{0 s}} \frac{2 \phi}{\pi M_{\infty}^{b}}=F(\phi) \\
& F(\phi)=-0.2504+0.8081 \phi-0.1829 \phi^{2} \\
& \quad-0.0971 \phi^{3}+0.1318 \phi^{4}
\end{aligned}
$$

ここで $b=(\pi / 2-\phi) / 3$ であり， $\beta_{0 \mathrm{~s}}$ は $\lambda=0^{\circ}$ のときの半頂 角 $\alpha$ に対しての斜め衝撃波角である。したがって，次式 より衝撃波角を求めることができる.

$$
\beta_{0}=\frac{\pi \beta_{0 s} F(\phi) M_{\infty}^{b}}{2 \phi}
$$

図中には前述の数值計算の結果も記入してあり，いずれも 実験値とよく一致することを示している。

4.2 表面上の流れ模様 フィンと平板上での油膜法に よる流れ模様の写真とこれらをもとにして描いた流線のス ケッチを第 4 図(a)〜 (e)に示す.

$\lambda$ が $30^{\circ}$ て $\alpha=12^{\circ}$ の場合, 平板上では衝撃波のかなり 前で主流が曲げられ収束しているが，完全に収束している かは微妙で一次はく離していてもかなり弱いものと考えら れる。しかし， $\lambda=30^{\circ} て ゙ \alpha=18 ， 24^{\circ}$ になると一次はく離 は明瞭になり，半頂角の増加につれて衝撃波と一次はく離 線の間隔が広がり，二次はく離線も見られるようになる。 平板上でフィンとの結合部近くでは三つのモデル共に同じ ような位置に再付着線が見られる。またフィン上でもはく 離が生じており，結合部て小さな渦を形成していることを 


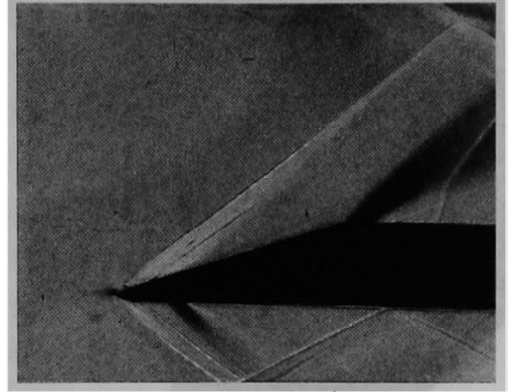

(a)

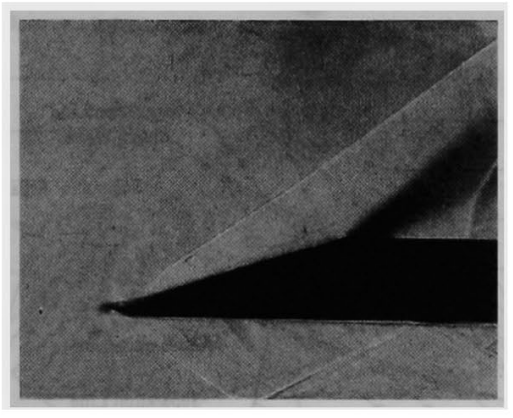

(b)

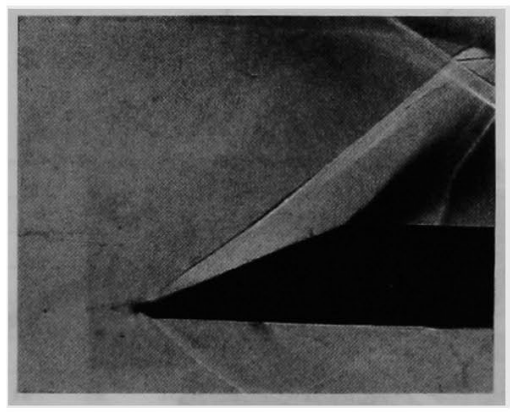

(c)

第2図 シュリーレン写真

(a) $\alpha=18^{\circ}, \lambda=15^{\circ}$, (b) $\alpha=18^{\circ}, \lambda=30^{\circ}$, (c) $\alpha$ $=24^{\circ}, \lambda=30^{\circ}$.

物語っている。なおこれらは $\boldsymbol{\alpha}$ に殆ど影響を受けていな いように見える。

次に $\alpha=18^{\circ}$ と一定にして $\lambda=15,30,45^{\circ}$ と変えた場 合, 衝撃波と一次はく離線の間隔の変化は小さく、いずれ の場合も平板上で一次と二次のはく離が生しており，入に よる相違は見られない。しかし再付着線については $\lambda$ が 大きくなると後方に移動していることが分かる.またフィ ン表面のはく離線については $\lambda=15^{\circ}$ の場合モデル先端に 近いところから伸びているのに対し， $\lambda=45^{\circ}$ になると見 られなくなる．以上より平板上の再付着線とモデル表面上 のはく離線の位置は，入に大きく影響されることが分か る.

油の流れ模様から読み取った上流影響線の位置 $L_{s}, L_{u}$ を第 5 図(a)に示す。ここでLs はモデルの頂点から衝橉 波面に沿って測った距離であり，Lu衝撃波から上流影 響線までの垂直に測った距離である。これより迎え角が大 きくなるにつれ，衝撃波と上流影響線の距離は離れていく
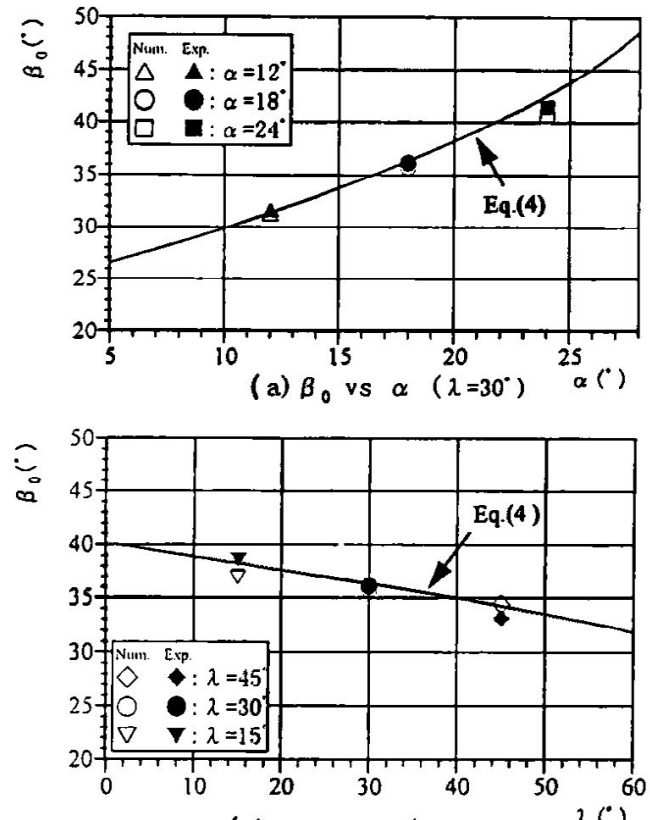

(b) $B_{0}$ vs $\lambda \quad\left(\alpha=18^{\circ}\right)$

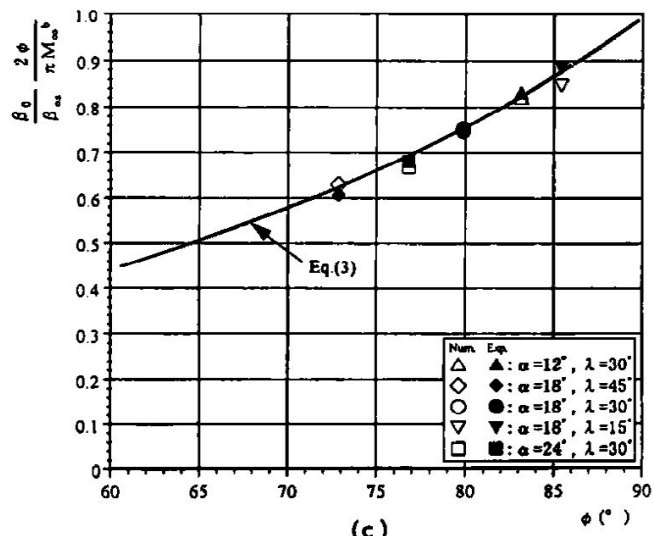

第3図 衝擊波角

(a) 半頂角との関係，(b) 後退角との関係,

(c) パラメータ $\phi$ との関係.

ことがわかる. Settles ら ${ }^{3.6)}$ は

$$
\begin{aligned}
& \overline{L_{\mathrm{s}}}=L_{\mathrm{s}} \operatorname{Re}_{\delta}^{1 / 3} \times 10^{-2} / \delta, \\
& \bar{L}_{\mathrm{u}}=L_{\mathrm{u}} \operatorname{Re}_{\delta}^{1 / 3} \times 10^{-2} / \delta
\end{aligned}
$$

とおいて $L_{\mathrm{s}}, L_{\mathrm{u}}$ を無次元化し，さらに $L_{\mathrm{u}}$ を $M_{\mathrm{n}}$ で割つ て表わすとフラットなフィンは迎え角と後退角に関係な く，一つの曲線で表すことができることを示した。ここで $R e_{\delta}$ は境界層厚さを基準長にとったレイノルズ数であり， $M_{\mathrm{n}}$ は非粘性衝撃波に垂直な主流マッ八数の成分である. 第 5 図(b)は本実験結果に適用した結果であり，この場合 も $\alpha, \lambda に$ 関係なく同一曲線上にのる，なお同図中の下側 の実線はSettles らによる種々のフラットなフィンについ ての上流影響線である。菱形三角フィンの上流影響線がフ ラットなフィンのより外側にくる理由は菱形三角フィンの 表面から平板の方に流れがあるためと考えられる.

第 6 図(a)は油の流れ模様から読み取った一次はく離線 角 $\beta_{31}$ を衝盤波角 $\beta_{0}$ に対してプロットしたものである． 同図中の白抜きの点は $\mathrm{Lu}^{13)}$ の行った非後退フィンによる 実験結果である。ここで主流マッハ数を考慮にいれ $\beta_{\mathrm{s} 1 \text {, }}$ 

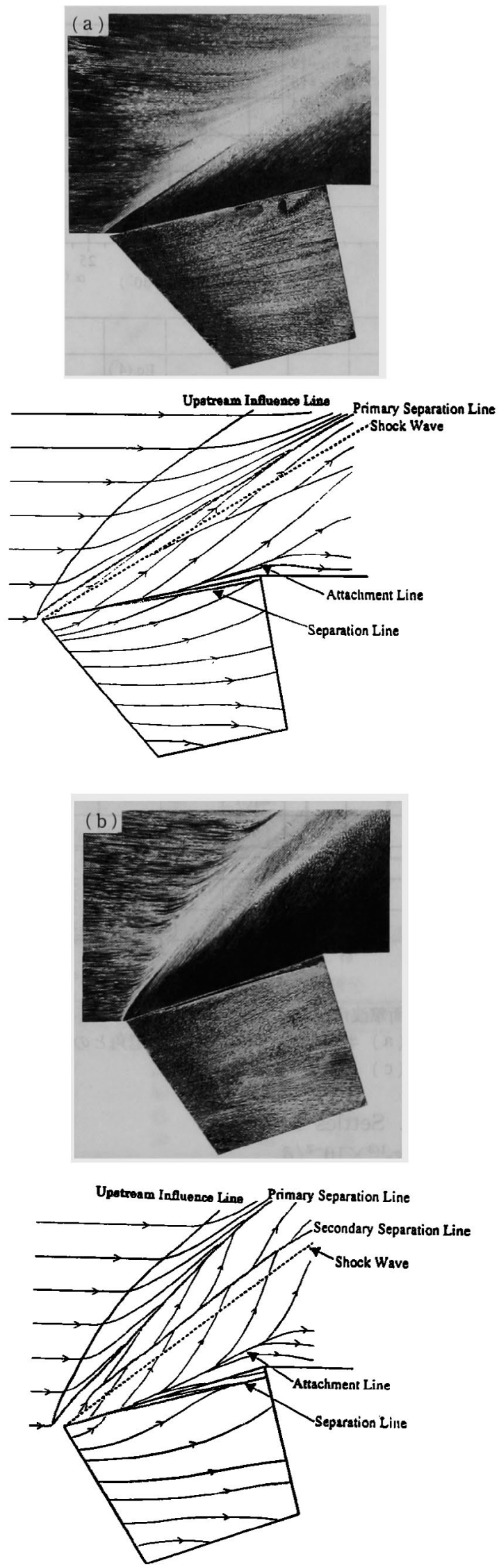

第 4 図 流れ模様の写真と流線のスケッチ

(a) $\alpha=12^{\circ}, \lambda=30^{\circ}$, (b) $\alpha=18^{\circ}, \lambda=15^{\circ}$, (c) $\alpha=18^{\circ}, \lambda=30^{\circ}$, (d) $\alpha=18^{\circ}, \lambda=45^{\circ}$.
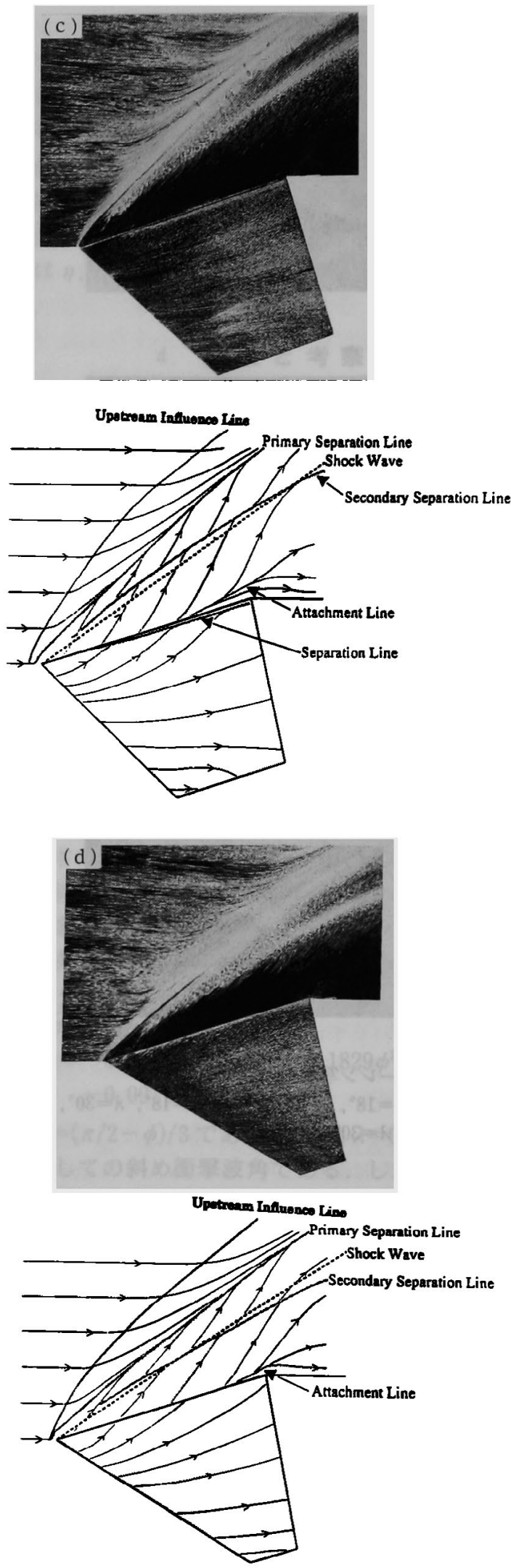


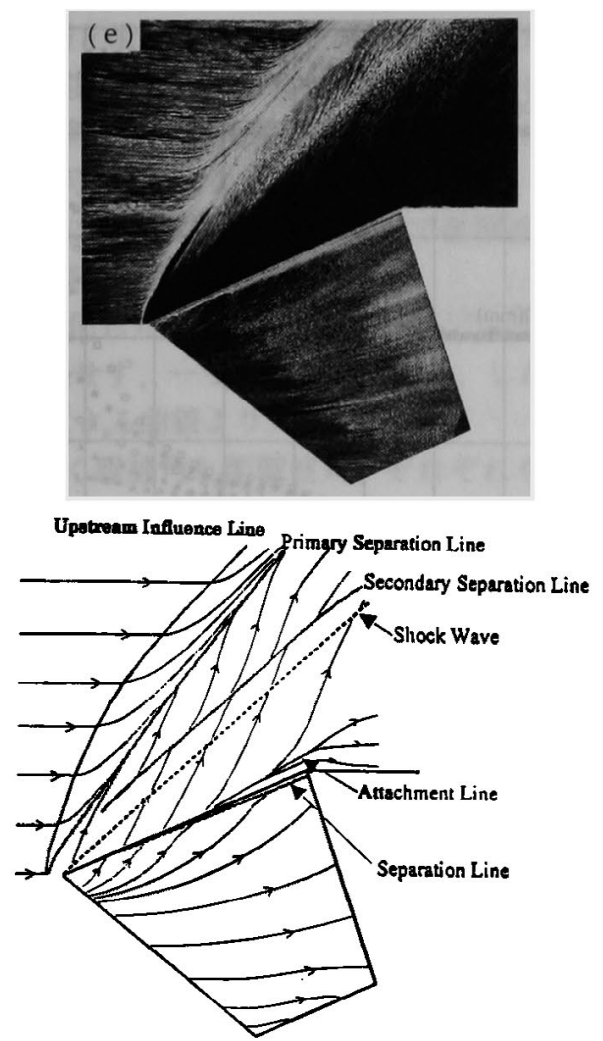

第 4 図続き (e) $\alpha=24^{\circ}, \lambda=30^{\circ}$.

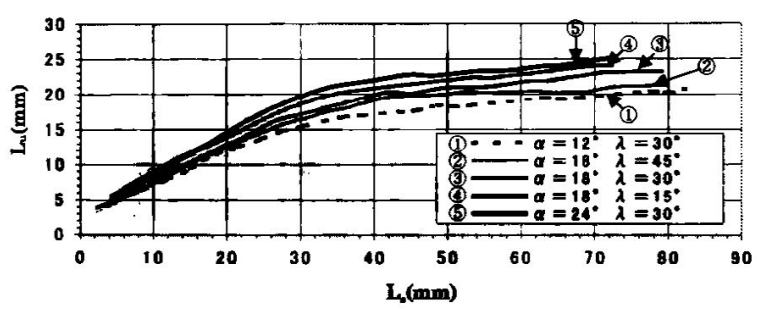

(a)

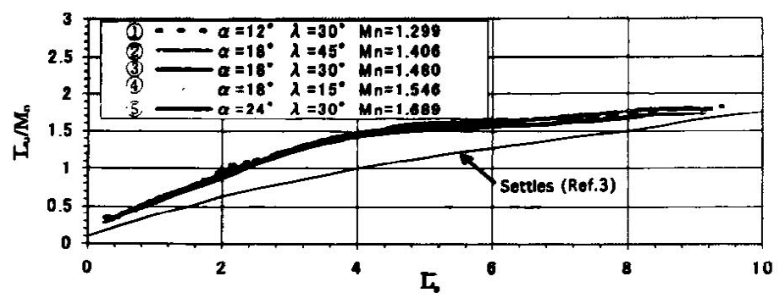

(b)

第 5 図上流影箱線

(a) 衡㢣波面からの距離, (b) 無次元表示.

$\beta_{0}$ それぞれを主流マッハ角的で引いた関係を第 6 図(b) に示す。これを見ると鋭いフラットなフィン, 菱形三角フ インともにほほ同一線上にのり $\beta_{31}-\mu_{\infty}$ と $\beta_{0}-\mu_{\infty}$ は線形 の関係にあることが分かる。

4.3 平板上の圧力分布 第 7 図(a)〜（c ）代代表的な モデルについて平板上での表面圧力分布をもとにして描い た等圧線図である. 同図中にはシュリーレン法によって観 察された衝撃波や油膜法からの一次はく離線が記入してあ る。一次はく離線と衝䖝波を延長した交点はモデルの頂点

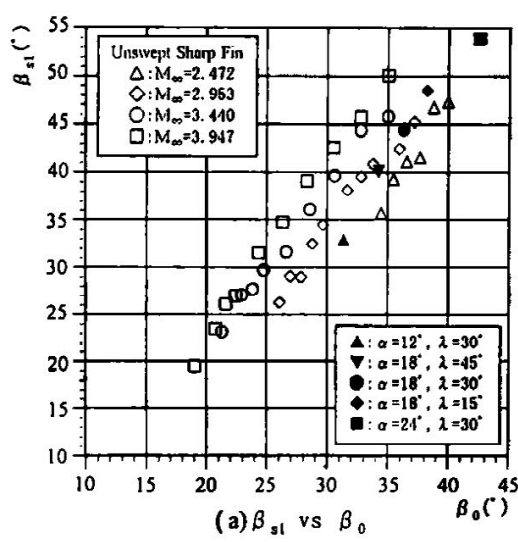

(a)

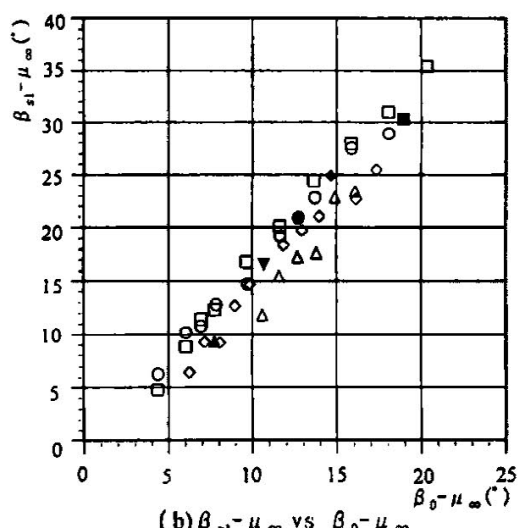

(b)

第 6 図一次はく離線角

（a）衝慗波角との関係，（b）マッハ角で引いた関係，

とは一致せず，その前方で交差していることが分かる，压 力比が 1.1 の等圧線を上流影響線とみなせば一次はく離線 と上流影響線はほほ平行になっており，Liaoと Deng に よって報告されている混合状態 (Mixing regime) に対応 している.なお一次はく離は压力比が 1.5〜1.6の位置で 起きるとされており，第7図(a)を除いてはそれに近い等 圧線上にある。しかし， $\alpha=12^{\circ}, \lambda=30^{\circ}$ のモデル（第 7 図(a)) では 1.4 に近く，このことからでは油膜法の写真 でも見られたようにはく離はかなり弱いものであると考え られる。

第 8 図は $\alpha=18^{\circ}, \lambda=30^{\circ}$ のモデルの頂点からある定ま った距離 $Y_{\mathrm{s}}$ の圧力份布を一様流からの角度 $\beta$ に対して整 理した結果である．同図には非粘性流としての数値解の結 果も記入した。これらより $Y_{\mathrm{s}}$ が異なっても上流影響線近 傍を除いてはほほ一致し，錘状流に近いことが確認でき る.またフィンと平板の結合部でのピーク压は非粘性流と しての数值解とほほ一致している.

第 9 図は衝撃波の位置 $X_{0}$ を原点にとって表した $X$ 方 向の圧力分布 $P / P_{\infty}$ を $Y$ をパラメータとしてプロットし たものである、いずれのモデルも衝撃波から上流影響線ま

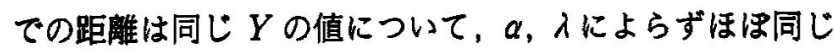
であることを示している. 压力曲線の波形はステップ，あ るいは円柱の前方で見られたのと同じで一次はく離に続く 


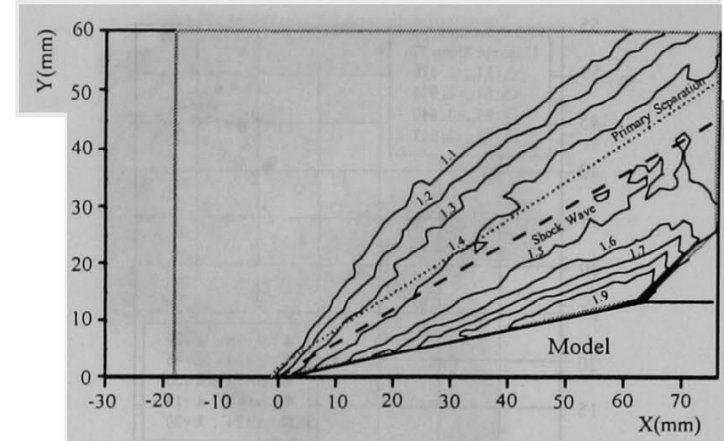

(a)

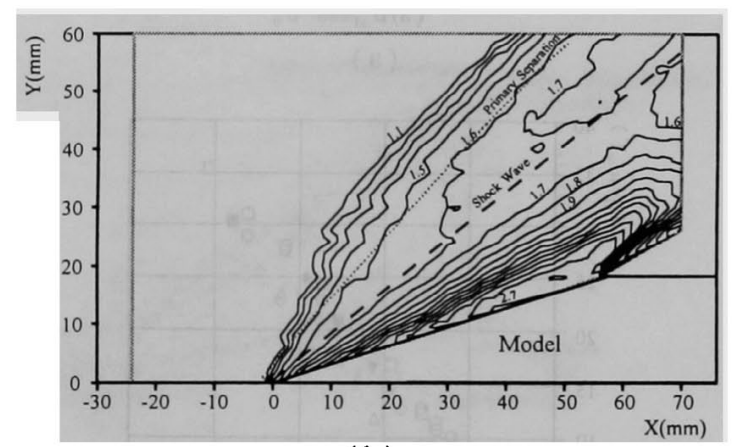

(b)

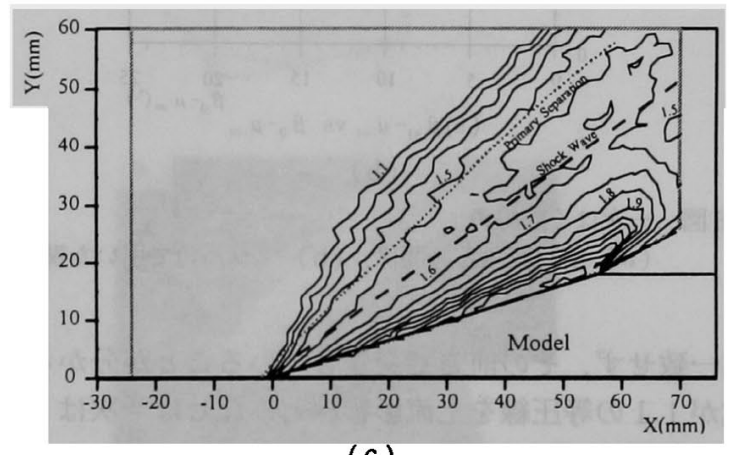

(c)

第 7 図 等压線図

(a) $\alpha=12^{\circ}, \lambda=30^{\circ}$, (b) $\alpha=18^{\circ}, \lambda=30^{\circ}$, (c) $\alpha$ $=24^{\circ}, \lambda=30^{\circ}$.

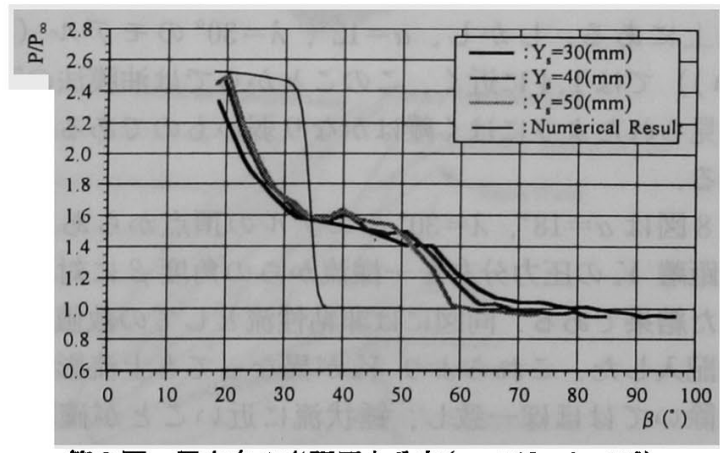

第 8 図 周方向の表面圧力分布 $\left(\alpha=18^{\circ}, \lambda=30^{\circ}\right)$

圧力一定のプラトー領域, さらに結合部近くでの再付着に よる圧力の急上昇というパターンである．ただプラトー領 域後方での圧力の降下がほとんど見られないことから弱い 洞しかできていないものと考えられる。いま各モデルのプ ラトー圧 $p_{\mathrm{pl}}$ とピーク圧 $p_{\mathrm{pk}}$ を衝擊波面に垂直な主流マッ

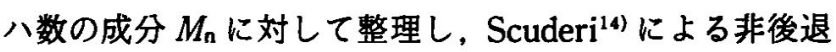

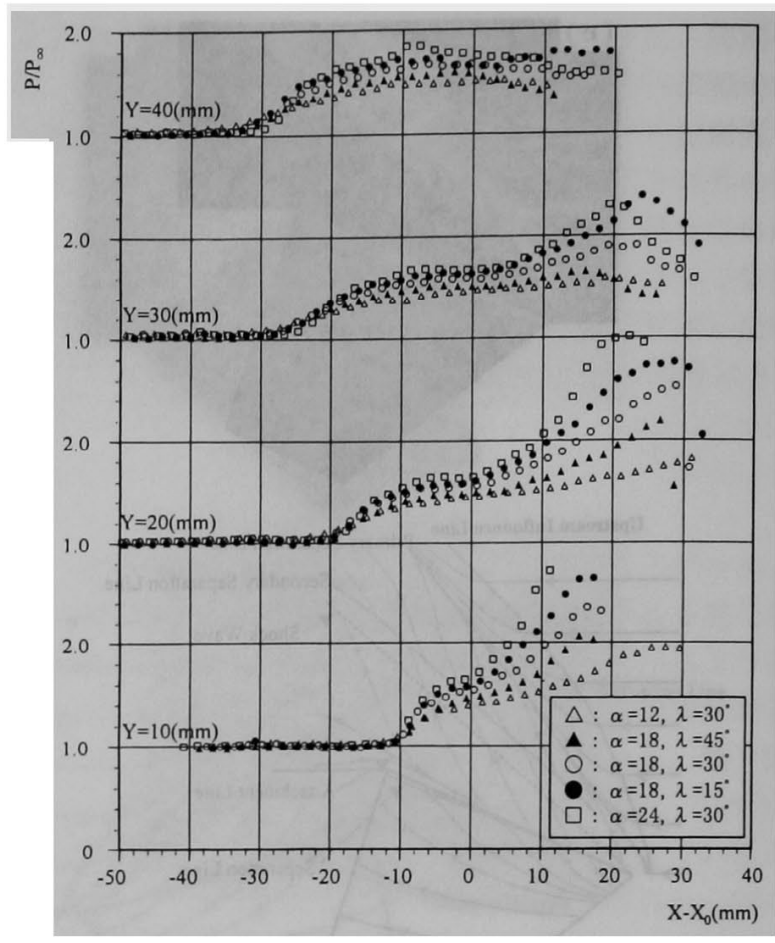

第 9 図 衝慗波の位置を原点にとった表面圧力分布

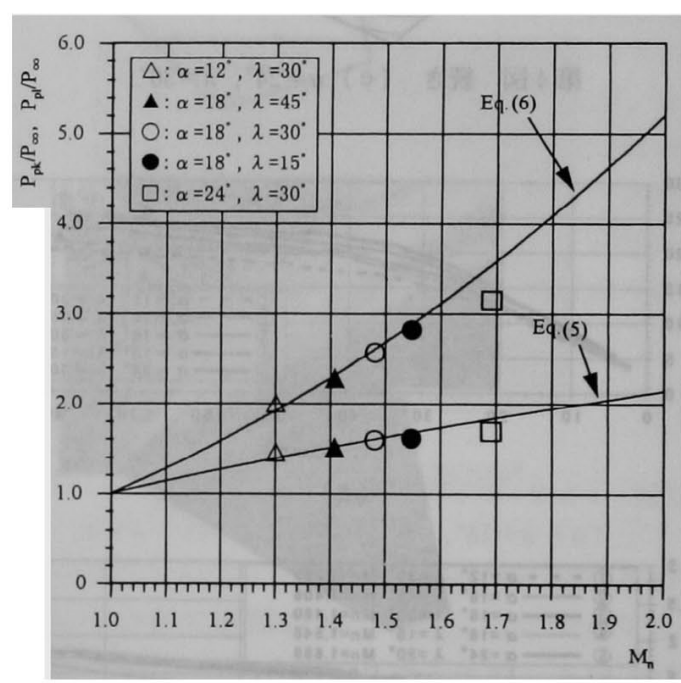

第 10 図 プラトー压、ピーク圧と衝擊波面に垂直な主流マッ 八数との関係

フィンについての実験式

$$
\begin{aligned}
& \frac{p_{\mathrm{pl}}}{p_{\infty}}=2.75 M_{\mathrm{n}}^{0.5}-1.75 \\
& \frac{p_{\mathrm{pk}}}{p_{\infty}}=1.167 M_{\mathrm{n}}{ }^{2.2}-0.167
\end{aligned}
$$

と比較した図を第 10 図に示す. $\alpha=24^{\circ}$ のモデルのピーク 圧を除いて上式は現在の夌形三角フィンにも大方適用でき ることが分かる。

以上の結果より衝撃波面に垂直な主流マッ八数の成分 $M_{\mathrm{n}}$ は流れを特徴づける重要なパラメータであることが分 かる.

\section{5. 結論}

超音速流中において平板上においた菱形三角フィンによ 
る乱流境界層と衝撃波の干涉をフィンの半頂角, 前緑後退 角を変えて実験を行い，つぎの事柄を明らかにした。

1) 菱形三角フィンの衝撃波角 $\beta_{0}$ への影響は後退角 $\lambda$ に よるよりも半頂角 $\alpha$ による方が大きい.

2）小出らによる簡易計算法によって衝撃波角 $\beta_{0}$ はパラ メータ

3）無次元化した上流影響線 $L_{\mathrm{u}}\left(R e_{\delta}{ }^{1 / 3} \times 10^{-2} / \delta\right) / M_{\mathrm{n}}$ は $\alpha$ と入に関係せず，一つの曲線で表せる。しかし鋭いフラ ットフィンによる曲線より大きい。

4）一次はく離線角と衝撃波角，それぞれを一様流のマ ッハ角で引いた量 $\beta_{\mathrm{s} 1}-\mu_{\infty}$ と $\beta_{0}-\mu_{\infty}$ は菱形三角フィン, 鋭いフラットフィン共に線形の関係にある。

5）菱形三角フィンの上流影響線と一次はく済線は，ほ 匢平行している。

6）プラトー圧, ピーク圧は, 衝撃波に垂直なマッハ数 $M_{\mathrm{n}}$ の小さいところてい鋭いフラットフィンによる Scuderi の式が成り立つ。

\section{参考 献}

1) Settles, G.S. and Dolling, D. S. : Swept Shock Wave/ Boundary-Layer Interactions, Tactical Missile Aerodynamics, Vol. 104, Hemsch, M. and Nielsen, J., eds., AIAA, New York, 1986, pp. 297-379.

2) Panaras, A.G.: Review of the Physics of Swept-Shock/ Boundary Layer Interactions, Prog. Aerospace Sci., 32 (1996), pp. 173-244.
3) Settles, G.S. and Lu, F. K. : Conical Similarity of Shock/ Boundary-Layer Interaction Generated by Swept and Unswept Fins, AIAA J., 23 (1985), pp. 1021-1027.

4) Settles, G. S. and Kimmel, R. L. : Similarity of Quasiconical Shock Wave/Turbulent Boundary-Layer Interactions, AIAA J., 24 (1986), pp. 47-53.

5) Lu, F. K., Settles, G.S. and Horstman, C. C.: Mach Number Effects on Conical Surface Features of Swept Shock-Wave/ Boundary-Layer Interactions, AIAA J., 28 (1990), pp. 91-97.

6) Lu, F. K. and Settles, G. S.: Upstream Influence Scaling of Sharp Fin Interactions, AIAA J., 29 (1991), pp. 1180-1181.

7) Liao, J. and Deng, $X .:$ A Simple Similarity Law of Conical Shock Wave, AIAA 94-2308, 1994.

8) Liao, J. and Deng, X. : Characteristic Flow Regimes of Swept Shock/Turbulent Boundary Layer Interactions, AIAA 950792, 1995.

9) Alvi, F.S. and Settles, G. S.; Physical Model of the Swept Shock Wave/Boundary-Layer Interaction Flowfield, AlAA J., 30 (1992), pp. 2252-2258.

10) Koide, S., Griesel, C. J. W. and Stollery, J. L. : Correlation of Shock Angles Caused by Rhombic Delta Wings, AIAA J., 34 (1996), pp. 1529-1531.

11) Koide, S., Saida, N. and Ogata, R. : Correlation of Separation Angles Induced by Glancing Interactions, ALAA J., 34 (1996), pp. 2198-2200.

12) Shankar, V., Anderson, D. and Kutler, P.: Numerical Solutions for Supersonic Corner Flow, J. Comp. Physics, 17 (1975), pp. 160-180.

13) Lu, F. K. : Private Communication.

14) Scuderi, L. F.: Expression for Predicting 3-D Shock WaveTurbulent Boundary Layer Interaction Pressures and Heating Rates, AIAA 78-0162, 1978. 